\title{
PENGUATAN EKONOMI MASYARAKAT MELALUI PENGELOLAAN KELEMBAGAAN BADAN USAHA MILIK DESA MENUJU ASEAN ECONOMIC COMMUNITY 2015
}

\author{
Muammar Alkadafi, S.Sos, M.Si \\ Dosen Jurusan Administrasi Negara Fakultas Ekonomi dan Ilmu Sosial \\ Universitas Islam Negeri Sultan Syarif Kasim Riau \\ Email : kadafimuammar55@yahoo.com
}

\begin{abstract}
Abstrak
Badan Usaha Milik Desa (BUM Desa) merupakan pilar kegiatan ekonomi di desa yang berfungsi sebagai lembaga sosial (social institution) dan komersial (commercial institution), BUM Desa sebagai lembaga sosial berpihak kepada kepentingan masyarakat melalui kontribusinya dalam penyediaan pelayanan sosial. Sedangkan sebagai lembaga komersial bertujuan mencari keuntungan melalui penawaran sumberdaya lokal (barang dan jasa) ke pasar. Pembentukan BUM Desa di desa Selensen mengacu pada Peraturan Daerah Kabupaten Indragiri Hilir Nomor 09 Tahun 2009 tentang Pedoman Pembentukan Badan Usaha Milik Desa. Metode penelitian yang digunakan dalam penelitian ini adalah penelitian kualitatif dengan fokus penelitian: (1) prosess pembentukan dan pelaksanaan kegiatan kelembagaan Badan Usaha Milik Desa (2) peran kelembagaan Badan Usaha Milik Desa dalam pengembangan ekonomi pedesaan. Hasil penelitian ini ialah, pelaksanaan kegiatan Badan Usaha Milik Desa di Desa Selensen sudah terlaksana dengan baik sesuai dengan tujuan pendirian kelembagaan, dan dapat dikatakan cukup berhasil. Kemudian, kelembagaan BUM Desa telah memberikan kontribusi positif bagi penguatan ekonomi di pedesaan dalam mengembangkan perekonomian masyarakat.
\end{abstract}

Kata Kunci : Kebijakan, Pemberdayaan, Kelembagaan Badan Usaha Milik Desa

\section{PENDAHULUAN}

Kebijakan pengembangan basis ekonomi di pedesaan sudah lama dijalankan oleh Pemerintah, baik itu Pemerintah Pusat, Pemerintah Provinsi, dan Kabupaten/Kota melalui berbagai program. Pogram tersebut dilaksanakan dalam berbagai bentuk, baik pemberian bantuan fisik maupun dalam bentuk bantuan dana (modal kerja), namun pada faktanya belum berjalan secara maksimal dan membuahkan hasil yang memuaskan sebagaimana diinginkan bersama. fenomena di lapangan menunjukkan, ketika program berakhir maka keluaran program tersebut sudah tidak berfungsi atau tidak terpelihara dan dilestarikan oleh masyarakat. Terdapat banyak faktor yang menyebabkan kurang berhasilnya program-program tersebut. Salah satu faktornya adalah program-program tersebut berjalan sendiri-sendiri menurut kebijakan departemen yang bersangkutan, dan tidak terintegrasi, parsial dan sektoral. faktor lainnya yang paling dominan adalah intervensi Pemerintah terlalu besar, akibatnya justru menghambat daya kreativitas dan inovasi masyarakat desa dalam mengelola dan menjalankan mesin ekonomi di pedesaan. Sistem dan mekanisme kelembagaan ekonomi di pedesaan tidak berjalan efektif 
dan berimplikasi pada ketergantungan terhadap bantuan Pemerintah sehingga mematikan semangat kemandirian.

Belajar dari pengalaman masa lalu, suatu pendekatan baru yang diharapkan mampu menstimuli dan menggerakkan roda perekonomian dipedesaan adalah melalui pendirian kelembagaan ekonomi desa yang dikelola sepenuhnya oleh masyarakat desa. Bentuk kelembagaan sebagaimana dimaksud adalah dinamakan Badan Usaha Milik Desa (BUM Desa). Badan usaha ini sesungguhnya telah diamanatkan di dalam UU No.32 Tahun 2004 tentang Pemerintahan Daerah, didalam pasal 213 ayat (1) disebutkan bahwa "Desa dapat mendirikan badan usaha milik desa sesuai dengan kebutuhan dan potensi desa". Kemudian, didalam Peraturan Menteri Dalam Negeri No. 39 Tahun 2010 Tentang Badan Usaha Milik Desa yang menyebutkan bahwa: "untuk meningkatkan kemampuan keuangan pemerintah desa dalam penyelenggaraan pemerintahan dan meningkatkan pendapatan masyarakat melalui berbagai kegiatan usaha ekonomi masyarakat pedesaan, didirikan badan usaha milik desa sesuai dengan kebutuhan dan potensi desa".

Pemerintah Kabupaten Indragiri Hilir sebagai salah satu daerah otonom yang berada di wilayah Provinsi Riau sebelum dikeluarkannya Permendagri tersebut sudah mengeluarkan kebijakan mengenai pendirian dan pembentukan BUM Desa melalui Peraturan Daerah Kabupaten Indragiri Hilir Nomor: 09 Tahun 2009 tentang Pedoman Pembentukan Badan Usaha Milik Desa (BUM Desa). Dan sampai dengan akhir tahun 2013 desa-desa di Kabupaten Indragiri Hilir sudah mendirikan sebanyak 18 (delapan belas) kelembagaan BUM Desa, Salah satu desa yang membentuk Badan Usaha Milik Desa di Kabupaten Indragiri Hilir adalah Desa Selensen Kecamatan Kemuning melalui Peraturan Desa Nomor 01 Tahun 2009 tentang Badan Usaha Milik Desa.
Tabel 1.1 : Daftar Badan Usaha Milik Desa (BUM Desa) Kabupaten Indragiri Hilir

\begin{tabular}{|c|c|c|c|c|}
\hline NO & $\begin{array}{l}\text { NAMA BUM } \\
\text { Desa }\end{array}$ & $\begin{array}{l}\text { NAMA } \\
\text { DESA }\end{array}$ & KEC & NO. PERDES \\
\hline 1 & $\begin{array}{l}\text { BUM Desa } \\
\text { Batu Bernai }\end{array}$ & Keritang & Kemuning & $\begin{array}{l}\text { No. } 2 \text { Thn } \\
2009\end{array}$ \\
\hline 2 & $\begin{array}{l}\text { BUM Desa } \\
\text { Selensen Salak }\end{array}$ & Selensen & Kemuning & $\begin{array}{l}\text { No. } 1 \text { Thn } \\
2009\end{array}$ \\
\hline 3 & $\begin{array}{l}\text { BUM Desa } \\
\text { Harapan } \\
\text { Barokah }\end{array}$ & Pekan Tua & Kempas & $\begin{array}{l}\text { No. } 1 \text { Thn } \\
2010\end{array}$ \\
\hline 4 & $\begin{array}{l}\text { BUM Desa } \\
\text { Jaya Bakti }\end{array}$ & $\begin{array}{l}\text { Teluk } \\
\text { Sungka }\end{array}$ & GAS & $\begin{array}{l}\text { No. } 2 \text { Thn } \\
2010\end{array}$ \\
\hline 5 & $\begin{array}{l}\text { BUM Desa } \\
\text { Rahmat }\end{array}$ & $\begin{array}{l}\text { Teluk } \\
\text { Kiambang }\end{array}$ & Tempuling & $\begin{array}{l}\text { No. } 5 \text { Thn } \\
2010\end{array}$ \\
\hline 6 & $\begin{array}{l}\text { BUM Desa } \\
\text { AL-AMIN }\end{array}$ & Bagan Jaya & Enok & $\begin{array}{l}\text { No. } 10 \text { Thn } \\
2009\end{array}$ \\
\hline 7 & $\begin{array}{l}\text { BUM Desa } \\
\text { Bukit } \\
\text { Berbunga }\end{array}$ & Batu Ampar & Kemuning & $\begin{array}{l}\text { No.1 Thn } \\
2010\end{array}$ \\
\hline 8 & $\begin{array}{l}\text { BUM Desa } \\
\text { Sakinah }\end{array}$ & $\begin{array}{l}\text { Sialang } \\
\text { Panjang }\end{array}$ & $\begin{array}{l}\text { Tembilan } \\
\text { Hulu }\end{array}$ & $\begin{array}{l}\text { No.1 Thn } \\
2010\end{array}$ \\
\hline 9 & $\begin{array}{l}\text { BUM Desa } \\
\text { Usaha Berkah }\end{array}$ & Sei.Undan & Reteh & $\begin{array}{l}\text { No.1 Thn } \\
2010\end{array}$ \\
\hline 10 & $\begin{array}{l}\text { BUM Desa } \\
\text { Gemilang } \\
\text { Pesisir }\end{array}$ & Sei.Bela & Kuindra & $\begin{array}{l}\text { No.1 Thn } \\
2010\end{array}$ \\
\hline 11 & $\begin{array}{l}\text { BUM Desa } \\
\text { Gemilang }\end{array}$ & $\begin{array}{l}\text { Tanjung } \\
\text { Baru }\end{array}$ & $\begin{array}{l}\text { Tanah } \\
\text { Merah }\end{array}$ & $\begin{array}{l}\text { No. } 1 \text { Thn } \\
2010\end{array}$ \\
\hline 12 & $\begin{array}{l}\text { BUM Desa } \\
\text { Benteng } \\
\text { Lestari }\end{array}$ & Benteng & $\begin{array}{l}\text { Sungai } \\
\text { Batang }\end{array}$ & $\begin{array}{l}\text { No.1 Thn } \\
2010\end{array}$ \\
\hline 13 & $\begin{array}{l}\text { BUM Desa } \\
\text { Mutiara Pesisir }\end{array}$ & $\begin{array}{l}\text { Concong } \\
\text { Luar }\end{array}$ & Concong & $\begin{array}{l}\text { No.1 Thn } \\
2010\end{array}$ \\
\hline 14 & $\begin{array}{l}\text { BUM Desaa } \\
\text { Citra Dana }\end{array}$ & $\begin{array}{l}\text { Harapan } \\
\text { Tani }\end{array}$ & Kempas & $\begin{array}{l}\text { No.1 Thn } \\
2010\end{array}$ \\
\hline 15 & $\begin{array}{l}\text { BUM Desa } \\
\text { Rasau Kuning }\end{array}$ & Pengalihan & Keritang & $\begin{array}{l}\text { No.1 Thn } \\
2010\end{array}$ \\
\hline 16 & $\begin{array}{l}\text { BUM Desa } \\
\text { Karya Mandiri }\end{array}$ & Lahang Baru & Gaung & $\begin{array}{l}\text { No.1 Thn } \\
2010\end{array}$ \\
\hline 17 & $\begin{array}{l}\text { BUM Desa } \\
\text { Beringin Jaya }\end{array}$ & $\begin{array}{l}\text { Pengalihan } \\
\text { Enok }\end{array}$ & Enok & $\begin{array}{l}\text { No.1 Thn } \\
2011\end{array}$ \\
\hline 18 & $\begin{array}{l}\text { BUM Desa } \\
\text { Sumber Rejeki }\end{array}$ & $\begin{array}{l}\text { Kelapa Patih } \\
\text { Jaya }\end{array}$ & $\begin{array}{l}\text { Telok } \\
\text { Belengkong }\end{array}$ & $\begin{array}{l}\text { No.1 Thn } \\
2011\end{array}$ \\
\hline
\end{tabular}

Sumber: Sekretariat PPD Kabupaten Indragiri Hilir Tahun 2013

Dari 18 (delapan belas) kelembagan BUM Desa yang terbentuk menurut hasil observasi penulis dan hasil ekspos Badan Pemberdayaan dan Pemerintahan Desa (BPMPD) Kabupaten Indragiri Hilir pada tahun 2012, yang menyebutkan bahwa kelembagaan BUM Desa yang berhasil dalam melaksanakan kegiatannya adalah BUM Desa Selensen Salak dari hasil penilaian yang dilakukan. Kemudian juga kelembagaan 
BUM Desa Selensen yang mengelola pasar desa, dan pasar desa tersebut mendapatkan juara 3 (tiga) nasional dari hasil penilaian Dirjen Otonomi Desa Kementerian Dalam Negeri Republik Indonesia.

Keberadaan kelembagaan Badan Usaha Milik Desa di Desa Selensen diharapkan dapat menjadi salah satu ikon dalam mewujudkan otonomi desa yang nyata sesuai dengan amanah UU Pemerintahan Daerah. Kemudian, kehadiran Badan Usaha Milik Desa akan menjadi penangkal bagi kekuatan korporasi asing dan nasional. Dengan demikian diharapkan Badan Usaha Milik Desa ini mampu menggerakkan dinamika ekonomi masyarakat desa. Di sisi lain, bagi pemerintah desa dapat mengelola aset-aset dan potensi desa dengan kreatif, inovatif dan mandiri melalui kepemilikan BUM Desa, sehingga dapat menciptakan lapangan pekerjaan baru di desa, memberikan pelayanan yang optimal bagi masyarakat dalam mengakses modal kerja. Selanjutnya, keberadaan kelembagaa BUM Desa sebagai agen pembangunan daerah dan menjadi pendorong terciptanya sektor korporasi di pedesaan.

\section{TINJAUAN PUSTAKA \\ 1. Definisi Kebijakan Publik}

Kebijakan publik menurut Chandler \& Piano (1998) dalam Tangkilisan (2003 : 1) adalah pemecahan masalah-masalah publik atau pemerintah. pendapat lain dikemukakan Thomas Dye (1981) dalam Subarsono, (2005 : 2) public policy is whatever the government choose to do or not to do (kebijakan publik adalah apapun pilihan pemerintah untuk melakukan sesuatu atau tidak melakukan sesuatu). Menurut Dye, apabila pemerintah memilih untuk melakukan sesuatu, maka tentunya ada tujua, karena kebijakan publik merupakan "tindakan" pemerintah. apabila pemerintah memilih untuk tidak melakukan sesuatu, inipun merupakan kebijakan publik, yang tentunya ada tujuan. Hal ini sejalan dengan pendapat Nugroho (2003 : 54) mendefinisikan kebijakan publik adalah halhal yang diputuskan pemerintah untuk dikerjakan dan hal-hal yang diputuskan pemerintah untuk tidak dikerjakan atau dibiarkan. Kesimpulan dari ketiga teori diatas yaitu suatu tujuan yang dilakukan atau tidak dilakukan di dalam lingkup aparatur pemerintah terhadap suatu kebijakan yang telah ditetapkan.

Menurut Carl Friedrich (1969) dalam Agustino (2012 : 7) menyatakan kebijakan publik adalah serangkaian tindakan/kegiatan yang diusulkan oleh seseorang, kelompok, atau pemerintah dalam suatu lingkungan tertentu dimana terdapat hambatan-hambatan (kesulitan-kesulitan) dan kemungkinankemungkinan (kesempatan-kesempatan) dimana kebijakan tersebut diusulkan agar berguna dalam mengatasinya untuk mencapai tujuan yang dimaksud.

Menurut James E. Anderson (1979) dalam Subarsono (2005: 2) kebijakan publik sebagai kebijakan yang ditetapkan oleh badan-badan dan aparat pemerintah. walaupun kebijakan publik dapat dipengaruhi oleh para actor dan faktor diluar pemerintah, dalam konteks ini kebijakan publik dipahami sebagai pilihan kebijakan yang dibuat oleh pejabat atau badan pemerintah dalam bidang tertentu, misalnya bidang pendidikan, politik, ekonomi, pertanian, industry, pertanahan dan sebagainya. Dan dalam pandangan David Easton ketika pemerintah membuat kebijakan publik, ketika itu pula pemerintah mengalokasikan nilai-nilai kepada masyarakat, karena setiap kebijakan mengandung seperangkat nilai didalamnya.

Sedangkan menurut Woll (1966) dalam Wahab (2008 : 6) kebijakan publik adalah sejumlah aktifitas pemerintah untuk memecahkan masalah di masyarakat, baik secara langsung maupun melalui berbagai lembaga yang mempengaruhi kehidupan masyarakat. 
Dari beberapa pengertian diatas dapat dipahami bahwa kebijakan publik itu harus mengabdi kepada masyarakat, maka dengan demikian dapat disimpulkan kebijakan publik adalah serangkaian tindakan yang ditetapkan dan dilaksanakan atau tidak dilaksanakan oleh pemerintah yang mempunyai tujuan atau berorentasi pada tujuan tertentu demi kepentingan seluruh masyarakat.

Dengan demikian dalam konteks menggerakkan ekonomi masyarakat dipedesaan pemerintah harus mengeluarkan kebijakan melalui badan-badan yang dimilikinya, satu langkah tepat yang dilakukan Pemerintah Provinsi Riau dalam usaha memperkuat perekonomian masyarakat pedesaan yakni dengan mengeluarkan kebijakan Program Pemberdayaan Desa (PPD) dengan mendirikan kelembagaan Usaha Ekonomi Desa Simpan Pinjam (UEDSP), di pedesaan yang ada di Provinsi Riau dengan tujuan untuk memecahkan masalahmasalah masyarakat pedesaan terutama dalam hal membantu masyarakat mengakses modal kerja. kemudian kebijakan tersebut ditindak lanjuti oleh kebijakan pemerintah Kabupaten Indragiri Hilir dengan mengeluarkan Peraturan Daerah tentang pembentukan Badan Usaha Milik Desa, dalam rangka memperkuat kelembagaan ekonomi pedesaan.

\section{Definisi Pemberdayaan Masyarakat}

Pemberdyaan

(empowerment)

merupakan konsep yang lahir sebagai bagian dari perkembangan alam pikiran masyarakat dan kebudayaan Barat, utamanya Eropa. Konsep pemberdayaan mulai tampak kepermukaan sekitar dekade 1970-an, dan terus berkembang sepanjang dekade 1980-an hinga 1990-an (akhir abad 20) Pranarka \& Moeljarto (1996, : 44)., mengungkapkan pemberdayaan masyarakat sebagai strategi pembangunan digunakan dalam paradigma pembangunan yang berpusat pada manusia. Perspektif pembangunan ini manyadari betapa pentingnya kapasitas manusia dalam meningkatkan kemandirian dan kekuatan internal atas sumber daya materi dan nonmaterial melalui redistribusi modal atau kepemilikan.

Salah satu teori pembangunan yang menjadi rujukan utama dalam pembangunan yang berbasis pada masyarakat tersebut adalah People centered development. Dalam implementasinya, pendekatan utama yang digunakan adalah pemberdayaan masyarakat. Pendekatan pemberdayaan digunakan karena diyakini sumber masalah kemiskinan dan keterbelakangan adalah ketidakberdayaan. Hal tersebut sejalan dengan pendapat Sumodiningrat (1997 : 165), yang mengungkapkan pemberdayaan masyarakat bertalian erat dengan upaya penanggulangan masalah-masalah pembangunan, seperti pengangguran, kemiskinan dan kesenjangan.

Menurut Chambers, 1995. dalam

Kartasasmita (1996:1-2) konsep pemberdayaan masyarakat juga mencakup pengertian pengembangan masyarakat (community development) dan pembangunan yang bertumpu pada masyarakat (community based-development). Pemberdayaan masyarakat adalah sebuah konsep pembangunan ekonomi yang merangkum nilai-nilai sosial. Konsep ini mencerminkan paradigma baru pembangunan yang bersifat "people-centered,participatory, empowering, and sustainable" ("berpusat pada rakyat, partisipatif, memberdayakan, dan berkelanjutan"). Kartasasmita, berpendapat bahwa pemberdayaan masyarakat dapat dilihat dari 3 (tiga) sisi yaitu; Pertama, menciptakan suasana/iklim yang memungkinkan potensi masyarakat untuk berkembang. Kedua memperkuat potensi daya yang dimiliki oleh masyarakat melalui langkah nyata menyangkut penyediaan berbagai masukan (input) serta pembukaan akses kedalam berbagai peluang yang membuat masyarakat menjadi makin berdaya, penyediaan fasilitas pelayanan kesehatan, 
informasi, modal, lapangan kerja, pasar dan perdagangan infrasturktur yang memadai. Ketiga memberdayakan mengandung pula arti melindungi, mencegah lemah menjadi bertambah lemah.

Sementara itu, Mubyarto (1984:15) mengungkapkan pemberdayaan ekonomi masyarakat adalah upaya untuk membangun daya ekonomi masyarakat yang mendorong, motivasi, dan membangkitkan kesadaran akan potensi ekonomi yang dimiliki masyarakat serta berupaya untuk mengembangkannya yang merangkum nilainilai sosial. Memberdayakan masyarakat berarti upaya untuk meningkatkan harkat dan martabat lapisan masyarakat yang dalam kondisi tidak mampu melapaskan diri dari perangkap kemiskinan dan keterbelaakngan. Dengan kata lain memberdayakan dalam memampukan dan memandirikan masyarakat dibidang ekonomi.

\section{Kelembagaan BUM Desa}

\subsection{Definisi Kelembagaan}

Menurut Erani, (2008:33), kelembagaan diberi predikat sebagai kerangka hukum atau hak-hak alamiah (natural rights) yang mengatur tindakan individu. Pada saat yang lain, kelembagaan dimengerti sebagai apapun yang bernilai tambahan atau kritik terhadap ilmu ekonomi klasik atau hedonik (hedonic economics). Bahkan, kelembagaan juga dimaknai sebagai apapun yang berhubungan dengan "perilaku ekonomi” (economic behavior). Secara definitif, kelembagaan bisa pula dimaknai sebagai regulasi perilaku yang secara umum diterima oleh anggota-anggota kelompok sosial, untuk perilaku spesifik dalam situasi yang khusus, baik yang bisa diawasi sendiri maupun dimonitor oleh otoritas luar (external authority) Rutherford (1994) dalam Erani (2008:33).

$$
\text { Selanjutnya, pendefinisian }
$$

kelembagaan bisa dipilah dalam dua klasifikasi. Pertama, bila berkaitan dengan proses, maka kelembagaan merujuk kepada upaya untuk mendesain pola interaksi antar pelaku ekonomi sehingga mereka bisa melakukan kegiatan transaksi. Kedua, jika berhubungan dengan tujuan, maka kelembagaan berkonsentrasi untuk menciptakan efisiensi ekonomi berdasarkan struktur kekuasaan ekonomi, politik dan sosial antarpelakunya, Erani (2008:35).

\subsection{Definisi Badan Usaha Milik Desa}

Badan Usaha Milik Desa (BUM Desa) adalah lembaga usaha desa yang dikelola oleh masyarakat dan pemerintahan desa dalam upaya memperkuat perekonomian desa dan dibentuk berdasarkan kebutuhan dan potensi desa. Didalam UU No. 32 Tahun 2004 tentang Pemerintahan Daerah BUM Desa didirikan antara lain dalam rangka peningkatan Pendapatan Asli Desa (PADesa). Dilihat dari fungsinya kelembagaan BUM Desa merupakan pilar kegiatan ekonomi di desa yang berfungsi sebagai lembaga sosial (social institution) dan komersial (commercialinstitution). BUM Desa sebagai lembaga sosial berpihak kepada kepentingan masyarakat melalui kontribusinya dalam penyediaan pelayanan sosial. Sedangkan sebagai lembaga komersial bertujuan mencari keuntungan melalui penawaran sumberdaya lokal (barang dan jasa) ke pasar. Dalam menjalankan usahanya prinsip efisiensi dan efektifitas harus selalu ditekankan. BUM Desa sebagai badan hukum, dibentuk berdasarkan tata perundang-undangan yang berlaku, dan sesuai dengan kesepakatan yang terbangun di masyarakat desa.

Adapun tujuan pendirian Badan Usaha Milik Desa (BUM Desa) adalah pertama, Meningkatkan perekonomian desa. Kedua, meningkatkan pendapatan asli desa. Ketiga, meningkatkan pengolahan potensi desa sesuai dengan kebutuhan masyarakat. Keempat, menjadi tulang punggung pertumbuhan dan pemerataan ekonomi pedesaan. 
Pendirian dan pengelolaan Badan
Usaha Milik Desa (BUMDes) adalah merupakan perwujudan dari pengelolaan ekonomi produktif desa yang dilakukan secara kooperatif, partisipatif, emansipatif, transparansi, akuntabel, dan sustainable.. Oleh karena itu, perlu upaya serius untuk menjadikan pengelolaan badan usaha tersebut dapat berjalan secara efektif, efisien, profesional dan mandiri.

Untuk mencapai tujuan BUMDes dilakukan dengan cara memenuhi kebutuhan (produktif dan konsumtif) masyarakat melalui pelayanan distribusi barang dan jasa yang dikelola masyarakat dan Pemdes. Pemenuhan kebutuhan ini diupayakan tidak memberatkan masyarakat, mengingat BUMDes akan menjadi usaha desa yang paling dominan dalam menggerakkan ekonomi desa. Lembaga ini juga dituntut mampu memberikan pelayanan kepada non anggota (di luar desa) dengan menempatkan harga dan pelayanan yang berlaku standar pasar. Artinya terdapat mekanisme kelembagaan/tata aturan yang disepakati bersama, sehingga tidak menimbulkan distorsi ekonomi di pedesaan disebabkan usaha yang dijalankan oleh BUMDes.

Jadi, ciri utama yang membedakan BUM

Desa dengan lembaga komersial lainnya adalah :

1. Badan usaha ini dimiliki oleh desa dan dikelola secara bersama;

2. Modal usaha bersumber dari desa $(51 \%)$ dan dari masyarakat (49\%) melalui penyertaan modal (saham atau andil);

3. Operasionalisasinya menggunakan falsafah bisnis yang berakar dari budaya lokal (local wisdom);

4. Bidang usaha yang dijalankan didasarkan pada potensi dan hasil informasi pasar;

5. Keuntungan yang diperoleh ditujukan untuk meningkatkan kesejahteraan anggota (penyerta modal) dan masyarakat melalui kebijakan desa (village policy);
6. Difasilitasi oleh Pemerintah Provinsi, Kabupaten, dan Pemerintah desa

7. Pelaksanaan operasionalisasi dikontrol secara bersama (Pemdes, BPD, anggota).

\section{Metode Penelitian}

Jenis penelitian yang dipakai di dalam penelitian ini adalah jenis penelitian kualitatif dengan pendekatan deskriptif. Sebagai landasan teori dalam memahami pendekatan metode kualitatif berdasarkan pendapat Bogdan dan Moleong (2002:03) mendefinisikan metode kualitatif sebagai prosedur penelitian yang menghasilkan data deskriptif berupa kata-kata tertulis atau lisan dari orang-rang dan perilaku yang dapat diamati. Deskriptif merupakan laporan yang berisi kutipan data untuk memberikan gambaran penyajian laporan. Data tersebut berasal dari naskah, wawancara, dan dokumen resmi lainnya. Fokus dalam penelitian ini adalah: (1) proses pembentukan dan pelaksanaan Kegiatan Badan Usaha Milik Desa, dan (2) peran kelembagaan Badan Usaha Milik Desa dalam Penguatan Ekonomi Desa.

\section{HASIL PENELITIAN DAN PEMBAHASAN}

\section{Gambar Umum Desa Selensen}

Desa selensen adalah satu diantara 11 (sebelas) Desa yang terdapat di Kecamatan Kemuning, Kabupaten Indragiri Hilir yang letaknya sangat strategis yakni berada di pinggir Jalan Lintas Timur dan berbatasan dengan Provinsi Jambi. Desa Selensen merupakan Ibukota Kecamatan Kemuning yang memiliki wilayah seluas 16.000 hektar dan jumlah penduduk sebanyak 3.085 jiwa, terdiri dari 923 kepala keluarga (KK). Masyarakat Desa Selensen mempunyai mata pencaharian di sektor pertanian, perkebunan, perdagangan, peternakan dan sektor jasa, dan pada saat ini yang paling menopang perekonomian masyarakat Desa Selensen 
adalah pada sektor perkebunan sawit dan karet yang menjadi andalan utama masyarakat, sehingga dengan demikian potensi ekonomi masyarakat di Desa Selensen dapat dikatakan cukup baik.

\section{Proses Pembentukan dan Pelaksanaan Kegiatan Badan Usaha Milik Desa di Desa Selensen}

Proses pembentukan kelembagaan Badan Usaha Milik Desa di Desa Selensen dimulai dari Kebijakan Program Pemberdayaan Desa (PPD) yang dikeluarkan oleh Pemerintah Provinsi Riau pada tahun 2005 dengan bentuk kegiatan ialah Usaha Ekonomi Desa Simpan Pinjam (UED-SP) yang sumber pendanaannya melalui sharing APBD Provinsi Riau dan Kabupaten Indragiri Hilir sebesar Rp. 500.000.000, yang alokasikan ke Desa Selensen. Kebijakan Program Pemberdayaan Desa (PPD) adalah merupakan turunan dari kebijakan Pemerintah Provinsi Riau yakni K2I (Kemiskinan, Kebodohan dan Infrastruktur). Dalam operasionalisasinya, kelembagaan UED-SP yang dijalankan sesuai dengan Peraturan Gubernur Nomor 15 tahun 2006 tentang Petunjuk Teknis Program Pemberdayaan Desa (PPD) Provinsi Riau menyebutkan bahwa pelaksanaan kegiatan UED-SP salah satunya adalah menyalurkan dana dalam bentuk bantuan dana bergulir untuk modal usaha kepada masyarakat dengan pendekatan pemberdayaan.

Pelaksanaan kegiatan UED-SP di Desa Selensen dimulai pada tahun 2006 dengan modal awal sebesar Rp. 500.000.000.- Kemudian dalam jangka tiga tahun pelaksanaan kegiatan kelembagaan UED-SP di Desa Selensen dilakukan perubahan status kelembagaan menjadi Badan Usaha Milik Desa (BUM Desa) setelah melalui proses musyawarah yang dilakukan oleh aparat desa, pengurus kelembagaan dan masyarakat desa, hal tersebut sesuai dengan alur proses pemberdayaan sebagai strategi kebijakan yang dibuat. Proses pembentukan BUM Desa di Desa Selensen didasari dengan Perda Nomor 09 tahun 2009 tentang Pedoman Pembentukan Badan Usaha Milik Desa dan Perdes Nomor 01 tahun 2009 tentang pendirian Badan Usaha Milik Desa. Adapun jenis usaha dan pengembangannya yang dikelola BUM Desa Selensen adalah Unit Usaha Simpan Pinjam, dan usaha pengembangannya adalah unit pengelolaan pasar desa dan pengelolaan listrik desa. Pengelolaa pasar desa tersebut juga sesuai dengan Perda Kabupaten Indragiri Hilir No. 16 Tahun 2009 tentang Pasar Desa, yang memberikan kewenangan pemerintaha desa untuk mengelola pasar desa. Kemudian pengadaan listrik desa di Desa Selensen ini diperoleh melalui bantuan Dinas Pertambangan dan Energi Kabupaten Indragiri Hilir yang dalam pengelolaannya juga diserahkan kepada pemerintah desa, dan dikelola oleh kelembagaan BUM Desa.

Jadi, proses pembentukan Badan Usaha Milik Desa di Desa Selensen dilakukan melalui proses yang panjang, yakni dimulai dengan pelaksanaan kegiatan UEDSP sebagai bentuk program kebijakan PPD Provinsi Riau. Setelah kegiatan UED-SP berjalan selama tiga tahun barulah dirubaha statusnya menjadi kelembagaan Badan Usaha Milik Desa. Hal itu sesui dengan amanat Surat Keputusan Bersama Menteri Dalam Negeri, Menteri Keuangan, Menteri Koperasi dan UKM, dan Bank Indonesia menyebutkan lembaga keuangan mikro dapat berubah status kelembagaannya berupa Koperasi, BUM Desa dan BPR.

\section{Peran Kelembagaan Badan Usaha Milik Desa Dalam Penguatan Ekonomi Desa.}

Dalam konteks peran kelembagan Badan Usaha Milik Desa dalam membantu masyarakat untuk pengembangan ekonominya sangat memberikan kontribusi yang positif terutama dalam hal akses modal 
dan pengembangan usaha masyarakat. Adapun usaha-usaha masyarakat di Desa Selensen dalam melaksanakan aktivitas ekonomi yaitu bergerak pada sektor perkebunan, perdagangan, pertanian peternakan, industri kecil dan jasa.

Tabel. 1.2 Jenis Usaha Pemfaat Dana BUM Desa Selensen Salak

\begin{tabular}{|c|l|c|r|}
\hline No. & Jenis usaha & $\begin{array}{c}\text { Jumlah } \\
\text { pemanfaat }\end{array}$ & \multicolumn{1}{c|}{ Rupiah } \\
\hline 1 & Perkebunan & 251 & $1,685,000,000$ \\
\hline 2 & Perdagangan & 183 & $1,020,000,000$ \\
\hline 3 & Pertanian & 135 & $1,050,000,000$ \\
\hline 4 & Peternakan & 58 & $97,000,000$ \\
\hline 5 & $\begin{array}{l}\text { Industri } \\
\text { kecil }\end{array}$ & 39 & $63,000,000$ \\
\hline 6 & Jasa & 34 & $85,000,000$ \\
\hline & Jumlah & $\mathbf{7 0 0}$ Orang & $\mathbf{4 , 0 0 0 , 0 0 0 , 0 0 0}$ \\
\hline
\end{tabular}

Sumber : Kantor BUM Desa Selensen Salak, 2013

Dari data diatas dapat disimpulkan bahwa melalui kelembagaan Badan Usaha Milik Desa (BUM Desa) sebagai lembaga ekonomi yang ada di Desa dapat berperan untuk memberikan akses modal kepada masyarakat untuk memanfaatkan potensipotensi yang ada di desa, dari data tersebut sebanyak 700 orang/pemanfaat dari tahun 2006 - 2013 secara akumulasi dana kelembagaan telah dialokasikan kepada masyarakat sebesar Rp. 4,0000,000,000,Dengan demikian, peran kelembagaan BUM Desa di Desa Selensen dapat menggerakkan roda perekonomian masyarakat desa, meningkatkan pengolahan potensi desa sesuai dengan kebutuhan masyarakat, dan dapat menjadi tulang punggung pertumbuhan dan pemerataan ekonomi masyarakat.

Kemudian, kontribusi lainnya dari keberadaan kelembagaan BUM Desa di Desa Selensen adalah pangaturan pengelolaan pasar desa, memberikan bantuan terhadap pembangunan infrastruktur pasar, kemudian juga dapat memberikan pelayanan dibidang penerangan atau pengelalan listrik desa, dan selanjutnya kelembagaan BUM Desa dapat memberikan kontribusi bagi peningkatan pendapatan desa, yakni dari laba usaha BUM Desa pada setiap tahunnya dialokasikan sebesar 10\% untuk Pendapatan Asli Desa (PADes).

\section{KESIMPULAN}

1. Proses pembentukan kelembagaan BUM Desa di Desa Selensen melalui tahapan selama 3 tahun yakni dari kelembagaan UED-SP menjadi BUM Desa, dan sudah sesuai dengan peraturan-peraturan yang mendasarinya. Dan dalam pelaksanaannya, kegiatan kelembagaan Badan Usaha Milik di Desa Selensen dapat dikatakan cukup berhasil, terutama dalam hal penyaluranan dana pada unit usaha simpan pinjam, dan unit usaha pasar desa. Hal ini dibuktikan dengan perguliran dan perputaran dana yang cukup signifikan pada unit simpan pinjam sampai pada 31 Desember Tahun 2013 sudah mencapai Rp. 4.000.000.000,- dan jumlah pemanfaat atau masyarakat yang menggunakan dana tersebut sudah mencapai 700 pemanfaat.

2. Peran Kelembagaan BUM Desa dalam penguatan ekonomi masyarakat telah telah menunjukkan hasil yang cukup positif, BUM Desa di Desa Selensen telah memberikan kontribusi dalam menggerakkan roda perekonomian masyarakat, meningkatkan pengolahan potensi desa sesuai dengan kebutuhan masyarakat, dan dapat menjadi tulang punggung pertumbuhan dan pemerataan ekonomi masyarakat. kemudian juga dapat memberikan kontribusi bagi Pendapatan Asli Desa (PADes) dalam meningkat Anggaran Pendapat Belanja Desa (APBDes). 


\section{DAFTAR PUSTAKA}

Agustino, Leo, 2008. Dasar-dasar Kebijakan

Publik, Penerbit Alfabeta, Bandung

Departemen Pendidikan Nasional, 2007. Pusat Kajian Dinamika Sistem Pembangunan (PKDSP), Fakultas Ekonomi Brawijaya, Malang

Erani, Ahmad, 2008 Ekonomi Kelembagaan. Bayumedia Publishing, Malang

Fakultas Ilmu Administrasi, Universitas Brawijaya Malang, 2006. Keberadaan Badan UsahaMilik Desa (BUM Desa) Sebagai Penguatan Ekonomi Desa, Jurnal Administrasi Publik (JAP), Vol. 1, No. 6, Hal. 1068-1076| 1068

Kartasasmita, Ginanjar. 1996. Pembangunan Untuk Rakyat, Memadukan Pertumbuhan dan Pemerataan. CIDES, Jakarta

Moleong, Lexy. J. 2002. Metode Penelitian

Kualitatif, Remaja Rosdakarya,

Bandung

Mubyarto, 1988. Pembangunan Pedesaan di Indonesia. Liberty untuk P3PK UGM,Yogyakarta

Pranarka \& Moeljarto, 1996 "Pemberdayaan (empowerment)" : Konsep, Kebijakan dan Implementasinya. (centre for strategic and internastional studies) Jakarta.

Ramadana Berlian Coristya, dkk. Jurnal Administrasi Publik (JAP), Vol. 1, No. 6,Hal. 1068-1076 FIA Universitas Brawijaya Malang.

Nugroho, Riant. 2003, Kebijakan Publik : Formulasi, Impelementasi, dan Evaluasi.

Subarsono, AG. 2006. Analisis Kebijakan Publik. Konsep, Teori dan Aplikasi, Pustaka Pelajar, Yogyakarta

Soemodiningrat, Gunawan. 1997. Membangun Perekonomian Rakyat, IDEA dan

Soetomo, 2011. Pemberdayaan Masyarakat Mungkinkah Muncul Antitesisnya.
Tangklisan, Hessel Nogi S. 2003. Kebijakan Publik yang Membumi, Konsep, Strategi dan Kasus. Lukman Effset, Yogyakarta.

Wahab,Abdul,Solichin. 2008. Pengantar Analisis Kebijakan Publik, UPT Penerbitan Universitas Muhammadiyah. Malang

\section{Referensi Lain :}

Undang- Undang 32 Tahun 2004 Tentang Pemerintahan Daerah

Peraturan Pemerintah Nomor 72 Tahun 2005 Tentang Desa

Peraturan Menteri Dalam Negeri Nomor 39

Tahun 2010 Tentang Badan Usaha Milik Desa

Peraturan Daerah Kabupaten Indragiri Hilir Nomor 09 Tahun 2009 Tentang Pedoman Pembentukan Badan Usaha Milik Desa (BUMDes) di Kabupaten Indragiri Hilir

Pentunjuk Teknis Program Pemberdayaan Desa (PPD) Propinsi Riau Oleh : Tim Koordinasi Pembinaan dan Pengendalian Program Pemberdayaan Desa Propinsi Riau tahun 2006, Dituangkan dalam Peraturan Gubenur Riau Nomor: 15 Tahun 2006.

Pedoman Umum Program Pemberdayaan Desa (PPD) Propinsi Riau Oleh : Tim Koordinasi Pembinaan dan Pengendalian Program Pemberdayaan Desa Propinsi Riau tahun 2006, Dituangkan dalam Peraturan Gubenur Riau Nomor: 15 Tahun 2006.

Pedoman Evaluasi Kerja Program Pemberdayaan Desa (PPD) Propinsi Riau Oleh : Tim Koordinasi Pembinaan dan Pengendalian Program Pemberdayaan Desa Propinsi Riau tahun 2006, Dituangkan dalam Keputusan Gubenur Riau Nomor: Kpts.No.KPTS.537/XII/2005 